\title{
Estimate the status of soil fertility and relationship beetween soil properties in Vertisols of Jaijaipur block in district Janjgir-Champa of Chhattisgarh
}

\section{KUMAR DHAR SAHU, R.N. SINGH AND HARISH KUMAR MAHLA}

Received : 16.06.2015; Revised : 18.10.2015; Accepted : 03.11.2015

\section{MEMBERS OF RESEARCH FORUM: \\ Corresponding author : KUMAR DHAR SAHU, Department of Soil Science and Agricultural Chemistry, Indira Gandhi Krishi Vishwavidyalaya, RAIPUR (C.G.) INDIA Email: kumardsahu111@gmail.com}

Co-authors :

R.N. SINGH AND HARISH KUMAR MAHILA, Department of Soil Science and Agricultural Chemistry, Indira Gandhi Krishi Vishwavidyalaya, RAIPUR (C.G.) INDIA

\begin{abstract}
Summary
The aim of the study was to assess the soil fertility status of Jaijaipur block in Janjgir- Champa district of Chhattisgarh covering 105 villages during 2011-2012. The geo-referenced surface $(0-0.15 \mathrm{~m})$ soils samples were systematically collected from village by using Global Positioning System where 279 samples identified as Vertisols The samples were analyze for DTPAextractable zinc, copper, iron, manganese, and available nitrogen, phosphorus and potassium content for delineation of the fertility status in relation to salient physico-chemical characteristics and categorized as low, medium and high as per criteria followed in the soil testing laboratory. It characterized slightly acidic to slightly alkaline in soil reaction, soluble salt content came under safe limit for all crops. The organic carbon level exhibited low to medium. The Vertisols of the area showed low in available $\mathrm{N}$ and $\mathrm{P}$, and medium to high level in available K. where micronutrient showed sufficient except Zn. Significant and positive correlations observed between soil $\mathrm{pH}$ and available $\mathrm{N}, \mathrm{P}$ and negative significant observed in $\mathrm{Mn}$ and $\mathrm{Zn}$. Electrical conductivity exhibited significant and positive relationship with available $\mathrm{K}$ and negative significant observed in Mn. Organic $\mathrm{C}$ showed significant and positive correlation with available $\mathrm{N}$ and $\mathrm{P}$ and negative significant observed in $\mathrm{Mn}$.
\end{abstract}

Key words : Fertility status, Soil properties, Micronutrients, Major nutrient, Vertisols, Correlation

How to cite this article : Sahu, Kumar Dhar, Singh, R.N. and Mahla, Harish Kumar (2015). Estimate the status of soil fertility and relationship beetween soil properties in Vertisols of Jaijaipur block in district Janjgir-Champa of Chhattisgarh. Asian J. Soil Sci., 10(2) : 237-241. 